Boise State University

ScholarWorks

Political Science Faculty Publications and

Presentations

Department of Political Science

$10-1-2012$

\title{
Participation, Representation, and Social Justice: Using Participatory Governance to Transform Representative Democracy
}

Brian Wampler

Boise State University 


\title{
Participation, Representation and Social Justice: Using Participatory Governance to Transform Representative Democracy
}

\author{
Brian Wampler \\ Boise State University
}

\begin{abstract}
The direct incorporation of citizens into complex policymaking processes is the most significant innovation of the "third wave" of democratization in the developing world. Participatory governance (PG) institutions are part of a new institutional architecture that increases the connections among citizens and government officials. This article draws from a single case of participatory governance to explore how its particular mechanisms work to transform representative democracy. In the cases examine here, PG institutions are grafted onto representative democracy and existing state institutions. These are state-sanctioned venues that require the intense involvement of citizens and government officials, without which the programs would grind to a halt. These features can expand citizen participation, enrich political representation, and enhance social justice.
\end{abstract}

"Representative government gives no institutional role to the assembled people." Bernard Manin ${ }^{1}$

"Democracy is not a static concept, whose essence could ever be decided one and for all. Rather, it is a dynamic and open-ended project....those faithful to the democratic project should look at the range of constraints and possibilities for furthering that project in particular times and places." " John Dryzek

\section{Introduction}

The direct incorporation of citizens into complex policymaking processes is the most significant innovation of the "third wave" of democratization, directly contradicting Manin's claim cited above and supporting Dryzek's claim regarding ongoing democratic innovations. Participatory institutions are being widely established across the world based on the perception that representative democracy is unable, on its own, to improve the quality of state performance, to allow citizens to exercise voice and vote in public arenas, to educate and empower citizens, and to make better use of scarce public resources. ${ }^{3}$

During the third wave of democratization, the field of political science concerned itself with democratic consolidation, presidentialism, party systems, and electoral systems as a means to promote stability in

\footnotetext{
${ }^{1}$ Bernard Manin, The Principles of Representative Government (New York, NY: Cambridge University Press, 1997), 8.

${ }_{2}^{2}$ John S. Dryzek, Deliberation Democracy and Beyond: Liberals, Critics, and Constestations (Oxford: Oxford University Press, 2000), 29.

${ }^{3}$ Boaventura Santos, "Democratizing Democracy: Beyond the Liberal Democratic Canon," (London: Verso, 2005).; Benjamin Barber, Strong Democracy: Participatory Politics For a New Age (Berkeley, CA: University of California Press, 1984). Archon Fung and Erik Olin Wright, Deepening Democracy: Institutional Innovations in Empowered Participatory Governance (London: Verso Books, 2003); Gianpaolo Baiocchi, "Participation, Activism, and Politics: The Porto Alegre Experiment," in Deepening Democracy: Institutional Innovations in Empowered Participatory Governance, ed. Archon Fung and Erik Olin Wright (London: Verso, 2003). Carole Pateman, Participation and Democratic Theory (Cambridge: Cambridge University Press, 1970).
} 
newly established democracies. ${ }^{4}$ But there was a parallel effort led by civil society activists and political reformers to change how representative democracy functions in order to overcome basic democratic deficits such as illiberal regimes, weak horizontal accountability, feeble electoral accountability, and hardto-sustain societal accountability. ${ }^{5}$ Thus the adoption of participatory governance is not a rejection of representative democracy but is part of an effort to overcome the basic problems associated with representative democracy while maintaining the advantages associated with voting and electoral accountability.

In this article, I argue that the new participatory institutional architecture is producing two types of change: First, there is a broadening of democratic process as citizens and civil society organization (CSO) leaders now engage the state and public officials in a variety of new public venues. ${ }^{6}$ This allows citizens to play three distinct roles in the democratic process: Citizens are participants in participatory venues, they are representatives elected to hold official positions within participatory venues, and others represent them in complementary public venues. ${ }^{7}$ The principal consequence of the broadening of the democratic process is that community activists are no longer forced to choose between contentious politics or clientelism, between autonomy or co-optation, between party politics and social movement organization. Rather, the participatory architecture now allows citizens and CSO leaders to deploy a wider range of political strategies. CSO leaders can work on electoral campaigns, join contentious demonstrations, forge alliances with party officials, and work on incremental policymaking. They can employ voice, vote, and exit across a variety of institutional venues. ${ }^{8}$

The second argument presented in this article is that many of the new participatory governance institutions promote social justice for two reasons: (1) As a means to address the glaring social inequalities and poverty in many developing world democracies and (2) to overcome the middle and upper class bias associated with representative democracy. I demonstrate how a set of specific rules geared toward modern, urban social settings now enable government officials and citizens to transform the often amorphous ideals of social justice and "development as freedom" into specific policy programs and outputs.

\footnotetext{
${ }^{4}$ Larry Diamond et al., Democracy in Developing Countries: Latin America (Boulder: Lynne Rienner, 1999). Adam Przeworski and Susan C. Stokes, Democracy, Accountability, and Representation (New York: Cambridge University Press, 1999).; Scott Mainwaring and Scully Timothy, "Introduction: Party Systems in Latin America," in Building Democratic Institutions: Party Systems in Latin America, ed. Scott Mainwaring and Timothy R. Scully (Stanford, CA: Stanford University Press, 1995). John Carey and Matthew Shugart, "Incentives to Cultivate a Personal Vote: A Rank Ordering of Electoral Formulas," Electoral Studies 14(1995); Guillermo O'Donnell, "The State, Democratization and Some Conceptual Problems: A Latin American View with Glances at Some Post-Communist Countries," in Democracy, Markets, and Structural Reform in Latin America, ed. William C. Smith, Carlos H. Acuma, and Eduardo A. Gamarra (New Brunswick, Connecticut: Transaction Publishers, 1994).

${ }^{5}$ Guillermo O'Donnell, "The State, Democratization and Some Conceptual Problems: A Latin American View with Glances at Some Post-Communist Countries," in Democracy, Markets, and Structural Reform in Latin America, ed. William C. Smith, Carlos H. Acuma, and Eduardo A. Gamarra (New Brunswick, Connecticut: Transaction Publishers, 1994); Matthew Cleary, The Sources of Democratic Responsiveness in Mexico (Notre Dame, IN: University of Notre Dame Press, 2010); Catalina Smulovitz and Enrique Peruzzotti, "Societal Accountability in Latin America," Journal of Democracy 11(2000)..

${ }^{6}$ Civil society organizations are an umbrella category including social movements, community-based organizations, NGOs, and third sector service providers. Following the Brazilian academic and political tradition, unions are a separate category.

${ }^{7}$ Michael Saward, The Representative Claim (New York: Oxford University Press, 2010).

${ }^{8}$ Alfred Hirschman, Exit, Voice, and Loyalty: Responses to Decline in Firms, Organizations, and States (Cambridge, MA: Harvard University Press, 1970).

${ }_{9}^{9}$ Amartya Sen, Development as Freedom (Oxford: Oxford University Press, 1999).
} 
Brazil is at the forefront of a broader world-wide efforts to directly incorporate citizens' voice and vote into incremental policymaking processes as well as an expanding public sphere. ${ }^{10}$ Today, hundreds of thousands of Brazilian citizens are elected to public policy management councils. There is also the ongoing mobilization of citizens into participatory budgeting and policy conferences, thus greatly expanding how policies are debated in the public sphere. This paper presents evidence from the Brazilian city of Belo Horizonte (population 2.3 million), but there is a substantial body of evidence of similar political renewal across the developing world including, increasingly, from the more established democracies. ${ }^{11}$

This article begins by explaining how participatory institutions complement the logic of representative democracy. The second section focuses on the links between participatory institutions and social justice. We now have considerable evidence that these new institutional types are increasing the allocation of public resources to low-income communities, thus overcoming the middle and upper class bias long associated with representative democracy.

To be clear: when I refer to PG mechanisms in this article, I am referring to those implemented in Belo Horizonte. While these arrangements form the empirical basis of my argument, my findings regarding the dynamics, effectiveness, and democratic implications of PG are generally suggestive of how PG can enhance representative democracy and promote social justice. The political reforms in Belo Horizonte place this city at the forefront of efforts in Brazil to fulfill the promise of the 1988 Constitution. These political transformation in Belo Horizonte illuminates the possibilities of change generated through the establishment of a broader participatory architecture.

\section{Complementing representative democracy}

Participatory governance institutions are grafted onto representative democracy and existing state institutions. Although social movements, unions or co-operatives often use participatory processes to govern themselves, the focus of this article is on state-sanctioned venues that permit citizens and government officials to exercise voice and vote. Participatory governance $(P G)$ is thus defined as the devolution of decision-making authority to state-sanctioned policy-making venues jointly controlled by citizens and government officials. Joint control does not mean that authority is equally distributed but rather

${ }^{10}$ Due to space considerations, it is not possible to explain why Brazil emerged as a leader in democratic innovation. The main reasons include the mobilization of civil society based on "the right to have rights" and "participatory publics", the growth of independent labor unions, the development of a new party system, and the promulgation of the 1988 Constitution, which municipalized service delivery, established social rights, and permitted direct citizen participation in government policymaking. See Leonardo Avritzer, Democracy and the Public Space in Latin America (Princeton, NJ: Princeton University Press, 2002); - - , Participatory Institutions in Democratic Brazil (Baltimore, MD: Johns Hopkins University Press, 2009); Gianpaolo Baiocchi, Patrick Heller, and Marcelo Silva, Bootstrapping Democracy: Transforming Local Governance and Civil Society in Brazil (Stanford, CA: Stanford University Press, 2011); Brian Wampler, Participatory Budgeting in Brazil: Contestation, Cooperation, and Accountability (University Park, PA: Pennsylvania State University Press, 2007).

${ }^{11}$ The evidence presented in this article was gathered by the author during the 2009-2010 academic year, when he was a Fulbright Scholar at the Federal University of Minas Gerais. For work, beyond Brazil see Donna Lee Van Cott, Radical Democracy in the Andes (New York, NY: Cambridge University Press, 2008); Stehpanie Mcnulty, Voice and Vote: Decentralization and Participation in Post-Fujimori Peru (Stanford, CA: Stanford University Press, 2011); Christopher Gibson and Michael Woolcock, "Empowerment, Deliberative Development, and Local-Level Politics in Indonesia: Participatory Projects as a Source of Countervailing Power," Studies in Comparative International Development 42, no. 2 (2008); Julien Labonne and Rob Chase, "Who is at the Wheel When Communities Drive Development? Evidence From the Philippines," World Development 37, no. 1 (2009); Yves Sintomer et al., "Learning from the South: Participatory Budgeting Worldwide - an Invitation to Global Cooperation," (Bonn, Germany: InWEnt gGmbH, 2010); Fung and Wright, Deepening Democracy: Institutional Innovations in Empowered Participatory Governance. 
that both citizens and government officials exercise voice and vote within the institution. The breadth of authority exercised by citizens is specific to each institutional type.

Analytically, the grafting of participatory governance institutions onto existing states and representative democracy produces change at five different contact points. First, participatory institutions are generally grafted onto public institutions at the local level, which means the breadth and intensity of change will vary greatly. Local state formation and fragmentation and the type of decentralization produce significant variation across policy arenas (education, health care, housing) and among cities and states.

Second, control of local state (often the mayor's office) through elections powerfully influences how PG institutions function. ${ }^{12}$ Thus, to understand the impact of PG involves analyzing the role of local party systems, political competition, the bases of political support for competitive parties, incentives for mayors to be responsive to voters or party loyalists, and the broader political project of the political parties. ${ }^{13}$ The local state (typically the mayor) is generally responsible for implementing the programs and policies selected by participants - this raises the possibility that some government officials may seek to promote social justice and human capabilities but others may seek to co-opt civil society activists.

Third, participatory institutions are a subset of broader policymaking processes, which means that resources and authority available to participatory institutions are generally limited. In the famous case of Porto Alegre's participatory budgeting, participants were able to influence between 10 and 15 percent of the annual budget. As a result of the strict parameters of their authority, participants are acutely aware of the need to lobby other state agencies as well as engage in party politics, demonstrations, and civil society mobilization to have their interests met. Citizens thus use participatory institutions as one institutional space among many political access points in pursuit of their interests. Some citizens may only work within one type of participatory institution, but many activists are involved in multiple venues.

Fourth, deliberative processes are used to expand the number and range of voices included in policymaking processes, thus expanding the number of signaling points that government officials use to gauge citizens' demands and needs. ${ }^{14}$ Participatory institutions ground citizens directly in deliberative processes whereby participants exercise vote to make specific policy decisions. Citizens have the right to exercise voice and vote beyond the constraints posed by the periodic elections associated with representative democracy. Participatory governance relies on ongoing formal and informal negotiations among citizens and between citizens and government officials-This is what distinguishes participatory processes from Deliberative Polling. In Deliberative Polling, randomly selected individuals are divorced from their daily lives and concerns, provided with information, and asked to express opinions. ${ }^{15}$ There is little to no follow-up when Deliberative Polling participants return to their everyday lives. Although Deliberative Polling has many virtues, the artificial divorce of citizens from their everyday political and policy concerns has the effect of limiting any potential transformative impact of the institution.

Fifth, participatory institutions often mirror practices long utilized in representative democracy. Citizensrepresentatives are elected, from among a broader pool of citizens, to hold "office." During their one or two year mandates, they act on behalf of their constituents, seeking to secure support for their policy and political goals. Participatory institutions also mimic duties carried out by the legislative branch-Citizen-

\footnotetext{
${ }^{12}$ There are a limited number of participatory governance institutions at the state, province and national levels, as they face considerable scaling problems. There are also participatory programs administered by international development agencies, such as the World Bank, which may not be directly housed within the local state. However, these programs should be considered part of a state-sanctioned process because the World Bank needs the active support of national states (the World Bank's client) and because the World Bank typically looks for allies and partners at the local level.

${ }^{13}$ Carey and Shugart, "Incentives to Cultivate a Personal Vote: A Rank Ordering of Electoral

Formulas." Mainwaring and Timothy, "Introduction: Party Systems in Latin America."

${ }^{14}$ Fung and Wright, Deepening Democracy: Institutional Innovations in Empowered Participatory Governance.

${ }^{15}$ James S. Fishkin, Democracy and deliberation: New directions for democratic reform (Yale Univ Pr, 1993).
} 
participants engage in oversight, present proposals, and divide work into sub-committees to prepare reports and policy proposals. Just as with other legislators, there is a specialization of interests, which leads to the professionalization of a smaller number of community activists thereby increasing their ability to act on behalf of their community members. Of course, as the leaders gain more information and contacts, they are often drawn into party politics and co-governance arrangements.

These five components show how participatory governance institutions are not divorced from representative democracy; instead, there is a symbiotic relationship between the two. Representative democracy allows for institutional innovations to overcome democratic deficits associated with it. Citizens and CSO leaders have in PG a wide range of opportunities to express voice, vote and exit, but they work within a political incentive structure strongly influenced by representative democracy.

\section{Transforming participation and representation}

The adoption of participatory institutions across the globe calls into question widely held assumptions about representative democracy. Bernard Manin argues that "(r)epresentative democracy is not a system in which the community governs itself, but a system in which public policies and decisions are made subject to the verdict of the people." ${ }^{16}$ As argued in the previous section, the grafting of participatory institution onto representative democracy allows citizens, paraphrasing Manin, to use PG to help their community govern itself. In addition, "the people" can exercise multiple types of votes, both within PG (e.g., specific projects, electing citizens to PB bodies) as well as via representative democracy (for mayor, city council).

When PG institutions are in place, citizens can participate in multiple venues, which alters how rights are claimed as well as how political representation unfolds. Citizens participate, are representatives and are represented inside and outside the PG institutions. David Plotke captures the complementary nature of participation and representation, which is a vital shift engendered by participatory governance:

The opposite of representation is not participation. The opposite of representation is exclusion. And the opposite of participation is abstention. Rather than opposing participation to representation, we should try to improve representative practices and forms to make them more open, effective and fair. Representation is not an unfortunate compromise between an ideal of direct democracy and messy modern realities. Representation is crucial in constituting democratic practices. ${ }^{17}$

Citizens are participants in participatory governance venues (e.g. attending meetings, listening, debates) but they are also representatives of those who are unable to attend (due to time or financial cost, work, care obligations, etc.). While citizens are acting as representatives, they are also represented by CSO leaders and party officials who claim to be acting in their behalf during deliberations and negotiations. Citizens thus play three distinct roles within participatory governance, those of "participant," "representative" and the "represented." 18

To illustrate this point: when there are large mobilizations (e.g., participatory budgeting meetings, policy conferences), individual citizens are participants promoting their interests, but they claim to be the representatives of friends, family, and neighbors unable to attend. During these large meetings, citizens also play the role of the "represented" as they often listen to deliberations led by a CSO leader, their representative, who advocates for their shared interests. CSO leaders claim to speak on behalf of their ordinary citizens, but the CSO leaders are also careful to show that they are part of a larger political movement in which they are participants, representatives, and represented.

In Belo Horizonte, during the first round of participatory budgeting meetings, this process was evidence. In 2010, CSO leaders from the Alta Vera Cruz shantytown organized buses to transport interested community members to the meeting. The presence of hundreds of ordinary citizens sent strong signals to government

${ }^{16}$ Manin, The principles of representative government., 192

17 David Plotke, "Representation is Democracy," Constellations 4, no. 1 (1997)., 19.

${ }^{18}$ Saward, The Representative Claim. 
officials regarding the community's capacity to mobilize and the strength of its commitment. ${ }^{19}$ During the meeting, CSO leaders engaged in public deliberation, spoke with their counterparts as well as with government officials, and picked up the necessary paperwork to allow them to enter their demands. CSO leaders acted as participants, but they also represented their communities.

Turning to the role of representation, it is useful to draw from Hanna Pitkin's classic work. Pitkin's concept of representation points us in the direction of theorizing where and when citizens might act as participants, as representatives, and as the represented.

Political representation is primarily a public, institutionalized arrangement involving many people and groups, and operating in the complex ways of large-scale social arrangements. What makes it representation is not any single action by any one participant, but the over-all structure and functioning of the system, the patterns emerging from the multiple activities of many people. ${ }^{20}$

PG institutions thus expand the number of institutionalized venues through which citizens seek to influence policy outcomes, an expansion enabling citizens to use a political scalpel rather than a sledgehammer to engage the policymaking process. Rather than having to rely on public demonstrations or agree to clientelistic bargains, both of which have long been among the limited political resources available to poor people in the developing world, citizens now gain access to basic public information on budgets, policies, and outcomes generated. The frequent meetings produce a body of knowledge among community leaders representing poor communities, which enables the leaders to more skillfully pursue their shared interests. Community leaders representing poor communities begin to build the networks and alliances that mirror those already utilized by the middle and upper classes.

There is a broadening of democratic venues in which citizens and CSO leaders act as participants, representatives and represented: There are now 41 municipal councils, 52 regional councils and 479 local level councils (e.g., schools, public health clinics). Among these 571 participatory venues, there are more than 3400 "seats" to which citizens can be elected or appointed. ${ }^{21}$ In addition, there are three forms of participatory budgeting, that brought over 50,000 residents to public meetings. Nearly 1800 citiziesn were elected from these participants to monitor the program. PB Digital drew over 110,000 votes in 2008. Finally, policy conferences brought at least 9,000 citizens to multi-day policy workshops. ${ }^{22}$ The expansion of institutional opportunities de-monopolizes control of the state and decision-making processes. Thus, there is the expansion of opportunities for citizens and CSO leaders to form their interests and design their political strategies without the overbearing intervention of political parties or entrenched politicians. Clientelistic exchanges remain present, but citizens can more easily exit the relations or use public venues to reveal details of these private exchanges. Public officials may continue to seek to co-opt CSO leaders, but these leaders can use public deliberation to maintain pressure on public officials; the latter may use their official responsibilities as representatives to hold up or even block government initiatives.

The new institutional architecture alters participation and representation by producing new intermediaries linking organized civil society and poor communities to the local state. The community leaders elected to participatory governance "offices" are commonly understood to be official state representatives, which often makes it easier for them to obtain information and access to government officials. It also increases their prestige within their own communities. The community leaders thus have increased opportunities to

19 Doug McAdam, John D. McCarthy, and Mayer Zald, Comparative Perspectives on Social Movements: Political Opportunities, Mobilizing Structures, and Cultural Framings (New York: Cambridge University Press, 1996).

${ }^{20}$ Hanna F. Pitkin, The Concept of Representation (Berkeley, CA: University of California Press, 1967)., 221-222, Italics added.

${ }^{21}$ Brian Wampler, Regenerating Democracy: Popular Participation, Social Justice, and Interlocking Institutions in Brazil. Unpublished book ms.

${ }^{22}$ Brian Wampler, Regenerating Democracy: Popular Participation, Social Justice, and Interlocking Institutions in Brazil. 
request and receive basic constituency service. If there is a problem in their community (i.e., sewage leakage, lack of drainage), the community leaders have the means to directly contact government officials to solicit support. Community leaders have a growing number of contacts and access points, which allows them to "shop around" to find solutions to their problems; they can exit from one political coalition or level of government as they seek solutions to their problems. ${ }^{23}$ The establishment of a broader number of contracts produces new networks, which gives community leaders the opportunity to reject exchanges that have limited benefits. CSO leaders don't have to rely on clientlistic brokers or on political parties, but can pursue multiple venues.

From the perspective of government officials, participatory institutions help them to identify key problems, demands, and grievances among the population, especially the most organized sectors. Elected officials who seek to represent specific constituencies now have better means to assess their constituents' needs and demands. Government officials then can better target their policy priorities by marrying citizens' demands with expert opinion. It also allows government officials to identify the policy issues most important to community leaders, which is important for policy and political purposes.

In competitive electoral environments it is obviously advantageous for elected officials to know which community leaders are the most successful at mobilizing citizens. Those leaders who can mobilize more individuals for participatory processes will also likely be able to mobilize individuals for campaign events as well as influence how they vote. Public officials thus use participatory institutions to easily identify which leaders are consistently able to mobilize citizens, which is obviously very valuable information during election cycles.

In 2009, I administered a survey to 300 community leaders in Belo Horizonte, Brazil in 2009 that sought to map their political activities. ${ }^{24}$ Over half of the CSO leaders indicated that they spoke with their neighbors and members of their organizations about specific candidates running for city council and mayor. I administered a second survey in two shantytowns ( $\mathrm{N}=328)$ with randomly selected citizens; $49 \%$ of the respondents indicated that they spoke with local community leaders about specific political candidates. From these surveys one can conclude that the policy and political information gathered by CSO leaders inside and parallel to participatory governance institutions now informs voter-level decisions. If we consider that electoral accountability depends on voters first having information to evaluate candidates and then acting on the information, participatory institutions can begin to fill in a major gap and help strengthen representative democracy. ${ }^{25}$ While CSO leaders act as participants and representatives in PG, they also act as linkages or intermediaries between elites and masses. Again, this shows how participation and representation are being transformed as elected officials and CSO leaders are both using these new venues to gather better policy and political information.

However, this blurring of the lines between participatory governance and representative democracy, along with the multiple roles played by CSO leaders, make co-optation of community leaders by government officials a real worry. Community leaders are aware that city-wide elections for mayor and city council tremendously impact how the participatory institutions will function; CSO leaders must continually weigh whether their alliances with political parties are based on mutually held interests or if their partnership will make them more susceptible to co-optation. The power differential between government officials and CSO leaders doesn't disappear with the advent of participatory democracy, but is transformed. CSO leaders and citizens now engage in a broad number of venues in pursuit of their interests.

Political parties have long played a key role in aggregating citizen opinion and in selecting government officials and public policies. A political party's rank and file act as the intermediaries, linking citizens to the party's elected officials. Participatory governance bypasses weak party systems as citizens and CSO leaders find new institutional means to connect to government officials. Given that many countries in the

\footnotetext{
${ }^{23}$ Hirschman, Exit, Voice, and Loyalty: Responses to Decline in Firms, Organizations, and States.

${ }^{24}$ For more information on the survey methodology, see Brian Wampler, Regenerating Democracy: Popular Participation, Social Justice, and Interlocking Institutions in Brazil. Space limitations don't allow for a detailed discussion. ${ }^{25}$ Cleary, The Sources of Democratic Responsiveness in Mexico.Cleary 2010
} 
developing world have fragmented party systems and few parties with clear policy agendas, PG provides a complementary mechanism for the exchange of information among government officials, citizens and CSOs. These new institutions are not substitutes for political parties, but they serve to fill in gaps in how citizen demands are represented as well as in how party officials identify new leaders.

In sum, participatory institutions now play a crucial role channeling demands emerging from organized communities into local governments. Citizens participate, they are representatives and they are represented. The blurring between state and society occurs as government officials and community leaders now occupy space within state institutions as well as within civil society networks.

\section{Participatory Governance and Social Justice}

To achieve social justice outcomes, participatory programs often establish specific rules that encourage the participation of poor citizens and communities. There is a pro-poor or preferential bias toward the poor. These institutional innovations are part of a broader "post-liberal" challenge whereby social movement are making demands for individual rights as well as group-based rights that recognize the profound differences of citizens. ${ }^{26}$ Yashar's research focuses on indigenous social movements in the Andean countries of Bolivia, Ecuador and Peru, but her broader point is applicable to participatory governance - there is a search for institutional arrangements that both guarantee individual-level rights and allow for group-based mobilization that redirects state authority and resources.

Participatory governance programs in the developing world focus on social justice due to widespread economic inequality and limited state provision of public services to poor neighborhoods; the institutionalization of these new venues provides the means to expand how representative democracy addresses fundamental differences in citizens' social well-being. Markets and states have been unable to generate the necessary bases of wealth or have been unwilling to distribute the wealth in more equitable fashions; the adoption of PG helps ensure that local states will allocate resources to poor and underserviced communities.

Based on my research, I have identified a set of approaches to state-sponsored social justice achieved through PG institutions: I call these approaches Techniques of Access. These consist of the broader set of rules, programs, and policies that make the amorphous qualities associated with social justice into specific, concrete improvements in social well-being. From the "right to food" to a reduction in malnutrition; From the "right to voice" to infrastructure projects in shantytowns. "Techniques of Access" are a set of institutional design principles of social justice-oriented participatory programs influenced by the work of Ostrom, and Fung and Wright. ${ }^{27}$ The design principles obviously share much in common with Fung and Wright, with the primary difference being that social justice concerns are addressed at each stage of the process (see Table 1).

\section{Table 1 about here}

Decentralize city-level government By establishing the key moment of decision-making at the submunicipal (local region, district) level, these programs induce competition over resources among individuals and groups who are from similar neighborhoods. Instead of poor communities having to compete against upper and middle class communities for scarce resources, poor communities are induced to negotiate, compete, deliberate, and share information with individuals from similar socio-economic and demographic profiles. This also increases the likelihood that individuals with low levels of education will participate and contribute to policy selection because they making decisions about policy and public goods in their communities

\footnotetext{
26 Deborah J. Yashar, Contesting Citizenship in Latin America: The Rise of Indigenous Movements and the Post Liberal Challenge (Cambridge: Cambridge University Press, 2005), 284-285.

27 Elinor Ostrom, Governing the Commons: the Evolution of Institutions for Collective Action Cambridge University Press (Cambridge: Cambridge University Press, 1990). Fung and Wright, Deepening Democracy: Institutional Innovations in Empowered Participatory Governance.
} 
Reward mobilization The allocation of resources based on need promotes social justice. This is part of a "post-liberal" challenge to democracy whereby individual citizens' access to state resources is based on the historical and social context. Poorer communities with more limited infrastructure (public facilities such as schools, health care clinics; private facilities such as banks, supermarkets, internet access) receive a greater share of the budget than better-off neighborhoods. The use of a "quality of life index," which inversely distributes resources based on a neighborhood's private and public infrastructure (schools, health care clinics, banks, churches), generates greater incentives for citizens from poor communities to participate.

In addition, recognizing that small shantytowns and the very poor face increased challenges to participate and will face difficulties in securing resources, micro-regions can be created to ensure resources are made available to them. This rule set recognizes the significant differences within poor communities, which create a bias in favor of larger communities able to organize themselves. Thus, explicitly establishing micro-regions creates a direct incentive for the most marginalized citizens to participate. What is produced is competition among participants as well as "bonds of solidarity." 28 The competition against other groups that have relatively similar characteristics places them on a more equal footing to secure benefits. Bonds of solidarity are established when these groups are able to build alliances.

Establish public fora: When policymaking focuses on public goods targeted towards poor communities' needs, there is a greater likelihood that poor citizens will use the public forums. For example, if a government has a housing program in a community where middle-income residents already have housing, then the wealthier citizens would have little incentive to participate, which would open up space for the poor. Social justice is then extended by focusing on policy concerns of primary importance to the poor.

The use of public fora is vital for three reasons. It allows citizens to place their demands in the public square, thereby permitting citizens to make the localized concerns and problems part of a larger debate. This moves the demand from being a particularistic need of their community (sewage, school) to a demand that is recognizable by a broad group of citizens. In turn, this establishes a common dialogue among civil society activists, which helps to build "bonds of solidarity." ${ }^{, 9}$ Finally, the public forums provide an important moment to directly engage government officials, which produces accountability.

Establish oversight mechanisms This is part of an ongoing process whereby citizens and governments exchange information about available resources, types of demands, and the feasibility of project implementation. This interaction also allows community leaders to get to know government officials, which creates interpersonal relationships that community leaders can access in an emergency or moment of great need. This would be an example of the "strength of weak ties" whereby community leaders move outside of their communities to have multiple connections to public officials. This type of network thus advances the specific project associated with participatory governance but it also advances the development of informal networks that are an integral part of governance regardless of regime type.

\section{Achieving social justice through participatory governance}

The final section of this paper provides a brief overview of how social justice has been extended in the most well-known and well-established cases of Brazil's participatory budgeting. Given the relative newness of these programs, the evidence is mixed and preliminary. The outcomes are mixed for the same reasons that results from other democratic governance programs are mixed-Their quality is dependent on a wide range of factors including socioeconomic conditions, civil society activity, partisan political competition, the role of deliberation, etc. What do we know?

Participatory budgeting is perhaps the most well-known case of participatory governance. ${ }^{30}$ It has now spread across the globe, with its strongest roots in Brazil and, to a less degree, Latin America. ${ }^{31}$ The basic

\footnotetext{
${ }^{28}$ Jeffrey C. Alexander, The Civil Sphere (Oxford, NY: Oxford University Press, 2006).

${ }^{29}$ Alexander, The Civil Sphere.

${ }^{30}$ Rebecca Abers, Inventing Local Democracy: Grassroots Politics in Brazil (Boulder, CO: Lynne Rienner Publisher, 2000); Gianpaolo Baiocchi, Militants and Citizens: The Politics of Participatory Democracy in Porto Alegre (Stanford, CA: Stanford University Press, 2005). Baiocchi, Heller, and
} 
principles behind participatory budgeting are that ordinary citizens are mobilized into local meetings in which they receive information about the municipal budget, they propose policy projects, they deliberate over policy projects, and they finally vote on which projects should enter the yearly budget. The municipal executive is heavily involved at each stage of the process, including the implementation phase, which is either done by municipal agencies or outsourced to private companies selected through a competitive bidding process. So, what do we know about participatory budgeting programs and social justice?

Two large, urban municipalities in Brazil, Porto Alegre and Belo Horizonte, have both had long-running participatory budgeting programs-Porto Alegre's begin in 1990 and Belo Horizonte's in 1993 and both are active as of 2011. There is good evidence that these two programs achieve policy outcomes that promote social justice. Table 4, below, shows how resources are distributed in Belo Horizonte relative to a neighborhoods degree of social vulnerability.

\section{Table 2 about here}

Table 2 demonstrates that the poorest neighborhoods with the least amount of public or private infrastructure received the greatest amount of resources both in absolute and per capita terms. This is a clear reversal of spending patterns in which upper and middle class neighborhoods traditionally received the lion's share of local resources.

The evidence is similar from Porto Alegre. Between 1996 and 2004, the government in Porto Alegre spent over US $\$ 400$ million. ${ }^{32}$ The work of Aldemir Marquetti shows that a greater percentage of resources was spent in communities that had very low standards of living. ${ }^{33}$ In addition, a growing body of evidence shows that participatory budgeting programs are associated with decreases in extreme poverty and infant mortality. ${ }^{34}$ Participatory budgeting thus appears to advance basic social justice outcomes.

Participatory budgeting programs are based on "Techniques of Access" whereby specific rules provide preferential bias in favor of poor and politically marginalized groups. These programs advance a broader social justice agenda because they specifically address how public resources and state authority should be used. The extensive and use of "Techniques of Access" inculcates the idea among citizens that participatory governance institutions should directly address the profound social and political differences among citizens. Thus, to democratize participatory institutions, it is important to provide incentives that induce poor and politically marginalized citizens to participate.

Silva, Bootstrapping Democracy: Transforming Local Governance and Civil Society in Brazil; Wampler, Participatory Budgeting in Brazil: Contestation, Cooperation, and Accountability.

${ }^{31}$ Mcnulty, Voice and Vote: Decentralization and Participation in Post-Fujimori Peru.; Benjamin Goldfrank, Deepening Local Democracy in Latin America: Participation, Decentralization and the Left (University Park, Pennsylvania: Pennsylvania State University Press, 2011); Van Cott, Radical democracy in the Andes; Sintomer et al., "Learning from the South: Participatory Budgeting Worldwide - an Invitation to Global Cooperation."

32 Wampler, Participatory Budgeting in Brazil: Contestation, Cooperation, and Accountability.

${ }_{33}$ Adelmir Marquetti, "Democracia, Equidade e Effciencia, o Caso do Orcçamento Participativo em Porto Alegre," in Inovaçāo Democrática no Brasil: O Orçamento Participativo, ed. Leonardo Avritzer and Zander Navarro (São Paulo: Cortez Editores, 2003).

${ }^{34}$ Carew Boulding and Brian Wampler, "Voice, Votes, and Resources: Evaluating the Effect of Participatory Democracy on Well-Being," World Development 38, no. 1 (2010). World Bank Report. 2008. "Brazil: Toward a More Inclusive and Effective Participatory Budget in Porto Alegre." Report No. 40144-BR. Touchton, Mike and Brian Wampler. Improving Social WellBeing through New Democratic Institutions, Paper presented at the 2012 Latin American Studies Association Conference, San Francisco, CA. 


\section{Conclusion}

Innovations in the field of participatory governance have been the most significant democratic institutional changes found in the past 20 years in the "Global South" or "Developing World." The new participatory governance architecture alters how citizens participate in public life by involving citizens in deliberative policymaking processes whereby their voice and their vote translate into policy change. The broadening of democratic venues has eroded political parties' traditional monopoly over state institutions and policymaking and reduced the power of entrenched public officials. . Citizens and civil society organizations (CSOs) use participatory institutions grafted onto representative democracy to pursue a greater range of strategies; these opportunities diminish the need for clientelism since citizens can use the new institutional venues to negotiate with multiple public officials. Contentious strategies such as public demonstrations can be combined with incremental policymaking efforts because CSOs enjoy a freedom of movement across this broader public sphere.

Participatory governance institutions in Brazil often include specific rules to address the middle and upper class bias associated with representative democracy. Advocates of PG institutions are not promoting citizen participation merely for the sake of participation, but as a means to mobilizing poor citizens to help them define and promote their own interests. The "Techniques of Access" are part of a broader "pos-liberal" challenge whereby CSOs representing poor and traditionally marginalized communities seek to gain the protections associated with representative democracy while also using institutional rules based on preferential bias in favor of poor citizens and communities. ${ }^{35}$ This approach starts from the premise that the profound inequalities among citizens can and should be addressed by new democratic institutions. In order to democratize democracy, the Techniques of Access provide specific incentives that induce poor citizens to participate. It is hoped that this will inculcate democratic rights among citizens who have long been excluded from having a substantial vote on collective decisions.

On a final note, we should expect that efforts to overcome basic democratic deficits associated with representative democracy through PG arrangements will produce sharply varied outcomes. Depending upon how PG institutions are grafted onto existing state institutions and representative democracy, there is likely to be significant differences in who participates, who can represent their fellow citizens, how citizens are represented, and the extent to which social justice can advanced. Researchers and reformers need to be attentive to the dynamic nature of this grafting process so that we can clearly understand when and how democratic deficits can be overcome through participatory institutions.

35 Yashar, Contesting Citizenship in Latin America: The Rise of Indigenous Movements and the Post Liberal Challenge. Yasher 2005 
Tables

Table 1

Promoting Social Justice

Participatory Governance Design Principles

\begin{tabular}{|c|c|}
\hline $\begin{array}{l}\text { Decentralize } \\
\text { city-level } \\
\text { government }\end{array}$ & $\begin{array}{l}\text { - } \\
\text { - } \quad \text { Links bureaucrats and policy experts at neighborhood level } \\
\text { - } \quad \text { Distributes resources on a per capita basis with poorer } \\
\text { neighborhoods receiving greater levels of funding. }\end{array}$ \\
\hline $\begin{array}{l}\text { Reward } \\
\text { mobilization }\end{array}$ & $\begin{array}{l}\text { - Permits citizens to directly vote on policy outcomes } \\
\text { - Draws attention to policy issues that have strong relevance to } \\
\text { targeted communities (e.g. basic infrastructure; health care clinics) } \\
\text { - Allocates resources based on need and population-poorer } \\
\text { communities receive greater levels of public resources }\end{array}$ \\
\hline $\begin{array}{l}\text { Expand } \\
\text { Deliberative } \\
\text { fora }\end{array}$ & $\begin{array}{l}\text { - Encourages citizens to debate each other and government officials } \\
\text { - Provides information to citizens to allow them to hold a more } \\
\text { substantive debate on government priorities and state responsibilities } \\
\text { - Permits citizens to question the (in)actions of government officials } \\
\text { and community leaders }\end{array}$ \\
\hline $\begin{array}{l}\text { Promote new } \\
\text { networks and } \\
\text { alliances }\end{array}$ & $\begin{array}{l}\text { - Links citizens to government officials; citizens to other citizens; } \\
\text { CSOs to CSOs } \\
\text { - Fosters growth alliances among poor } \\
\text { - Establishes new intermediaries in the absence of strong parties. }\end{array}$ \\
\hline $\begin{array}{l}\text { Engage in } \\
\text { oversight }\end{array}$ & $\begin{array}{l}\text { - Allows citizens and CSOs to monitor policy implementation } \\
\text { - Helps citizens to gather information about ongoing policy efforts } \\
\text { - Promotes more efficient and effective use of state funds }\end{array}$ \\
\hline
\end{tabular}

Table 2

Belo Horizonte: Resource Allocation in PB (1994-2008)

\begin{tabular}{|l|l|l|l|l|l|}
\hline $\begin{array}{l}\text { Social } \\
\text { Vulnerability } \\
\text { of region }\end{array}$ & $\begin{array}{l}\text { \# of } \\
\text { Public } \\
\text { Works }\end{array}$ & Population & $\begin{array}{l}\% \text { of city } \\
\text { Population }\end{array}$ & $\begin{array}{l}\text { Resources } \\
\text { spent** US } \\
\text { dollars }\end{array}$ & $\begin{array}{l}\% \text { of total } \\
\text { PB } \\
\text { resources }\end{array}$ \\
\hline High & 529 & 761,453 & 34 & 312 Million & 57 \\
\hline Medium & 350 & 849,611 & 38 & 180 Million & 33 \\
\hline Low & 121 & 627,224 & 28 & 55 Million & 10 \\
\hline Total & 1000 & & & 547 Million & 1000 \\
\hline
\end{tabular}

Source: Wampler, Regenerating Democracy 